\title{
REVIEW \\ F.J.E. Boddens Hosang \\ Establishing Boundaries: \\ Christian-Jewish Relations in Early Council Texts and the Writings of Church Fathers \\ Jewish and Christian Perspectives, Vol. 19
}

(Brill: Leiden and Boston, 2010)

Geoffrey D. Dunn, Australian Catholic University

This revised doctoral dissertation seeks to examine Christian relations with or treatment of other religious groups, particularly Jews, by considering church legislation about Jews in the years after Christianity became an accepted and favored religion early in the fourth century. Christian canonical legislation has not had much influence on studies of this relationship. This makes the idea of this book a valuable one, for canonical material does reflect real concerns rather than merely theological ones (without wishing to disparage the latter). This approach in turn brings a fresh look at questions of how dynamic Judaism was in the centuries after the destruction of the Temple in 70 and the parting of the ways between Judaism and Christianity. The argument seems to be that looking at theological literature alone has led scholarship to a stalemate.

The first chapter summarizes scholarship on these two questions. The trouble with brief summaries of extensive scholarship is that the subtlety of argument can be lost, and that is the case here. Further, having spent several pages canvassing scholarship on these two questions, the author does not take a position. The scholarship is summarized but never really engaged.

The various chapters that follow consider some early Christian synods (Elvira in chapter one, Laodicea in chapter two, the Apostolic Canons in chapter three, and various Gallic synods 
of the fifth and sixth centuries in chapter four). There is extensive background information in each chapter, along with archaeological evidence. This is helpful for someone with no background knowledge of early Christianity. However, the backgrounds, although very interesting, are so extensive that the main purpose of each chapter, which is to examine what the canons produced by synods say about Jews and Christians, tends to get lost. What is the relevance of that information for the promulgation and interpretation of the canons? Thus, in the chapter on Elvira, discussion starts on p. 23, but it is not until p. 40 that we get to the canons. Even though that continues until p. 75, it is not as substantial as it first appears. For example, canon 49 is about trying to stop Christian farmers from having their lands blessed by Jews. Most of the discussion is about blessings and not enough about the canon itself and what it says about Jews.

This seems to be a volume full of excursuses. The background is not related to this material on the canons and is often superfluous and gratuitous. In particular, why do we get material on the Cappadocians in chapter two (on the synod of Laodicea)? They came from an area far from Laodicea (Anatolia is a large area densely populated with Christians in late antiquity). There is a lengthy discussion about Gaul in the final chapter. While the author says that the canonical texts will be placed in that historical context (p. 125), there is little interaction between the context and the texts.

In the third chapter we are presented with the Apostolic Canons, where the presumption is made that they reflect some synod. The material concerning Jews is slight and the chapter is fleshed out by first considering the anti-Judaic or antijudaizing homilies of John Chrysostom simply because he came from Antioch, where this document may also be from. This could be helpful if some real connection between the two existed, but the author acknowledges in the conclusion to the chapter that there are also parallels with the synod of Laodicea. Yet even this claim of some relationship between the documents from the two cities is a dubious one. 
In the introduction the author says that he will re-read early Christian anti-Judaic literature in the light of the canonical legislation. However, because of the way this author presents the material (theological writings and archaeological data first, canonical legislation second), this does not happen except too briefly in each chapter's conclusion. The conclusions to each chapter are thought-provoking and insightful, although far too concise to fulfil the objective established in the introduction.

There are minor weaknesses. The use of Patrologia Latina or Patrologia Graeca when there are more recent and better critical editions of ancient works and an inconsistency of referencing (e.g., p. 19 nn. 60 and 61) shows a lack of scholarly maturity. Indeed, that some works are referenced with their Latin titles and others by their English ones (e.g., p. 24) suggests too much dependency upon variations found in secondary literature and not enough independence of writing. Calling the Didache (p. 25 n. 75) a document of a meeting is inaccurate. Sometimes the Apostolic Canons is in italics (p. 53) and sometimes it is not (pp. 46, 53). The claim made on p. 129 that the bishop of Arles was made primate is misleading, in that he was actually made metropolitan over several provinces. As well, the claim that Patroclus was bishop of Narbonne is simply wrong; that was Hilary. Patroclus was the bishop of Arles.

This is an interesting topic for a monograph and one well worth a thorough and detailed examination. While this volume may be of use to someone who knows little about early Christianity, it fails to be what is needed as an investigation into early canonical material on the relationship between Jews and Christians and in relating that material to the wellsurveyed body of literature. 